ARTICLE

https://doi.org/10.1038/s41467-019-09870-y

\title{
Acceleration of dolomitization by zinc in saline waters
}

Veerle Vandeginste (10 ${ }^{1,2}$, Oliver Snell ${ }^{1}$, Matthew R. Hall ${ }^{2,3}$, Elisabeth Steer ${ }^{4} \&$ Arne Vandeginste ${ }^{5}$

Dolomite $\left(\mathrm{CaMg}\left(\mathrm{CO}_{3}\right)_{2}\right)$ plays a key role in the global carbon cycle. Yet, the chemical mechanisms that catalyze its formation remain an enigma. Here, using batch reactor experiments, we demonstrate an unexpected acceleration of dolomite formation by zinc in saline fluids, reflecting a not uncommon spatial association of dolomite with Mississippi Valley-type ores. The acceleration correlates with dissolved zinc concentration, irrespective of the zinc source tested $\left(\mathrm{ZnCl}_{2}\right.$ and $\left.\mathrm{ZnO}\right)$. Moreover, the addition of dissolved zinc counteracts the inhibiting effect of dissolved sulfate on dolomite formation. Integration with previous studies enables us to develop an understanding of the dolomitization pathway. Our findings suggest that the fluids' high ionic strength and zinc complexation facilitate magnesium ion dehydration, resulting in a dramatic decrease in induction time. This study establishes a previously unrecognized role of zinc in dolomite formation, and may help explain the changes in dolomite abundance through geological time.

\footnotetext{
${ }^{1}$ School of Chemistry, University of Nottingham, University Park, NG7 2RD Nottingham, UK. ${ }^{2}$ GeoEnergy Research Centre, University of Nottingham, University Park, NG7 2RD Nottingham, UK. ${ }^{3}$ British Geological Survey, Environmental Science Centre, Keyworth, NG12 5GG Nottingham, UK. ${ }^{4}$ Nano- and Microscale Research Centre, University of Nottingham, University Park, NG7 2RD Nottingham, UK. ${ }^{5}$ Camco Technologies, Haasrode Research Park 1040, Technologielaan 13, 3001 Leuven, Belgium. Correspondence and requests for materials should be addressed to V.V. (email: veerle.vandeginste@nottingham. ac.uk)
} 
$\mathrm{G}$ lobal warming, triggered by the rapid increase of anthropogenic carbon dioxide and other greenhouse gas emissions, is a major concern and calls for the need to better understand the global carbon cycle ${ }^{1,2}$. The carbonate reservoir of the Earth's crust accounts for the major component of global carbon storage. Dolomite $\left(\mathrm{CaMg}\left(\mathrm{CO}_{3}\right)_{2}\right)$ stores $14 \%$ more carbon per unit volume, and is less prone to chemical weathering, than the only carbonate mineral that is more abundant on Earth, calcite $\left(\mathrm{CaCO}_{3}\right)$. The rare occurrence of dolomite in recent marine sedimentary systems (despite modern oceans being supersaturated with respect to dolomite) in contrast to its abundance in ancient sedimentary systems remains an enigma ${ }^{3,4}$. Dolomite can be found, for example, in hypersaline lagoon sedimentary environments and in burial settings where dolomite may spatially occur alongside ore deposits. It has proven to be extremely challenging to form crystallographically well-ordered dolomite in the laboratory under ambient conditions due to the slow reaction kinetics 5 . The unfavorable kinetics have been attributed mainly to the strong hydration enthalpy of magnesium ions ${ }^{6}$, the large energy barrier for long range ordering of $\mathrm{Mg}^{2+}$ and $\mathrm{CO}_{3}{ }^{2-}$ ions in the crystall, and lattice stress buildup linked to the impurity incorporation model ${ }^{8,9}$ and self-limiting growth model ${ }^{10,11}$. Despite the lack of convincing evidence of successful laboratory synthesis of dolomite at ambient temperature ${ }^{12}$, experimental studies demonstrate that the formation of protodolomite, a precursor of dolomite, is favored by dissolved sulfide $^{13}$ in contrast to dissolved sulfate under certain conditions ${ }^{14,15}$ (debated by some authors ${ }^{6,16,17}$ ), by high salinity ${ }^{14}$, microbial mediation such as sulfate-reducing bacteria ${ }^{15,18}$, extracellular polymeric substances ${ }^{19,20}$, and carboxylated surfaces on organic matter $^{21}$. Despite the research conducted to date, the chemical pathways behind the catalysis of dolomitization (calcite-to-dolomite replacement) remain poorly understood.

Previous research investigating factors affecting the kinetics of dolomite formation predominantly built on the common association of dolomite with salt lakes and lagoons ${ }^{14}$. In addition to those environments, dolomite is also often the host rock of zinc ores of the Mississippi Valley-type (MVT) ${ }^{22-24}$. Interestingly, zinc ions have a hydration enthalpy stronger than that of magnesium ions despite a similar ionic radius ${ }^{25}$. Moreover, zinc drives mineralization leading to the formation of kidney stones ${ }^{26}$ or bladder stones, documented to contain dolomite in some cases $^{27}$. Furthermore, carbonic anhydrase (CA), a Zn-containing metalloenzyme, accelerates the formation of calcium carbonate, for example in sponge spicules ${ }^{28}$, and in alkaline solutions ${ }^{29}$. The role of zinc in each of these earth science, chemistry, and biology contexts is striking; yet, no previous research has investigated the impact of dissolved zinc on the reaction pathways and kinetics of dolomitization.

Here, we demonstrate for the first time that a radically different, previously rarely explored effector-namely zinc ions in saline solutions-acts as an efficient catalyst for dolomitization. Moreover, the experimental data show that the catalytic effect of zinc counteracts the inhibiting effect of sulfate on dolomite formation. Our findings may help explain the common spatial association of dolomite with MVT ore formation, establish a previously unrecognized link between the geochemical cycles of carbon and zinc with the involvement of abiotic carbonate formation, and may increase our understanding of dolomite abundance through geological time.

\section{Results}

Batch reactor experiments. We postulate that the competitive binding affinity of $\mathrm{Zn}$ with a range of ligands to form complexes and its flexible coordination $(4,5$, and 6$)$, in comparison with $\mathrm{Mg}$ (and $\mathrm{Ca}$ ) ions, enhances $\mathrm{Mg}^{2+}$ dehydration, facilitating incorporation of $\mathrm{Mg}$ in the crystal structure, and thus resulting in a catalytic effect of $\mathrm{Zn}$ ions on dolomite formation from $\mathrm{Zn}$ bearing solutions. To test this hypothesis, we conducted calciteto-dolomite replacement batch reactor experiments at $200^{\circ} \mathrm{C}$ in which $200 \mathrm{mg}$ of calcite was reacted with $15 \mathrm{ml}$ of simulated natural brines containing $2.00 \mathrm{M} \mathrm{NaCl}, 0.30 \mathrm{M} \mathrm{MgCl}_{2}$ and $0.20 \mathrm{M} \mathrm{CaCl}_{2}$ in the control series, and added $\mathrm{ZnCl}_{2}(0.01$, $0.03,0.05,0.10$, and $0.20 \mathrm{M}$ ) in fluids of the same ionic strength of 3.5 (by reducing the concentration of $\mathrm{NaCl}$ ) in the $\mathrm{ZnCl}_{2}$ experiments.

Reaction pathway. Detailed powder X-ray diffraction (PXRD) analysis of the reaction products shows that the dolomitization reaction occurs in three stages: first an induction period; followed by a conversion stage of the reactant, Mg-poor calcite, to protodolomite; and finally a recrystallization stage of protodolomite to well-ordered dolomite. This transition from calcite to protodolomite is detected by the shift in the (104) peak (Fig. 1), whereas protodolomite and dolomite are distinguished by an ordering (015) peak (Fig. 2). Besides calcite, protodolomite and dolomite, we have identified traces of brucite, $\operatorname{Mg}(\mathrm{OH})_{2}$, and simonkolleite, $\mathrm{Zn}_{5}(\mathrm{OH})_{8} \mathrm{Cl}_{2} \bullet\left(\mathrm{H}_{2} \mathrm{O}\right)$, in the reaction products from the control series and the $\mathrm{ZnCl}_{2}$ experiments, respectively. The presence of simonkolleite in the reaction products is even more pronounced in an additional experimental series where zincite $(\mathrm{ZnO})$ was used instead of $\mathrm{ZnCl}_{2}$ (Fig. 3). The corresponding geochemical elemental data imply that zincite dissolves in the saline solution at $200^{\circ} \mathrm{C}$ within the first $3 \mathrm{~h}$ (Fig. 3). Moreover, since the $\mathrm{Zn}$ concentration in the reaction products lacks a distinct correlation with (proto)dolomite content (Supplementary Fig. 1), it is interpreted to be caused by the presence of simonkolleite, rather than significant incorporation of $\mathrm{Zn}$ in the (proto)dolomite structure. Hydrothermal dolomite hosting MVT deposits may contain ppm to $\%$ contents of $\mathrm{Zn}$, and zincian dolomite has been considered a peripheral hydrothermal hypogene alteration product in Polish ore deposits ${ }^{30}$, and a low temperature supergene alteration product of primary sulfide deposits in Jabali (Yemen), Iglesias (SW Sardinia), and Yanque $(\text { Peru })^{31}$

Many replacement reactions have been shown to involve interface-coupled dissolution-precipitation ${ }^{32,33}$, which is probably the key pathway in the second stage of the dolomitization reaction. With abundant $\mathrm{Ca}^{2+}$ and $\mathrm{Mg}^{2+}$ available in the solutions by addition of soluble chloride salts but no dissolved carbonate, some calcite must dissolve to enable new carbonate formation. Hence, calcite dissolution and the formation of protodolomite are intimately coupled and must take place at the fluid-mineral interface. The new crystals have been reported to grow epitaxially onto the dissolving calcite surface $^{33}$, in contrast to spherulitic crystal growth, as documented in direct dolomite precipitation experiments ${ }^{34}$. The third stage involves Ostwald ripening dissolution-reprecipitation during transformation of protodolomite to dolomite. The dolomite product from this stage is crystallographically well-ordered and stoichiometric $\left(50\right.$ mole $\% \mathrm{MgCO}_{3}$ ) in each of the experiments, thus irrespective of the presence of zinc or sulfate ions in the solution. The stoichiometry of the dolomite precipitates is likely favored by the $\mathrm{Mg} / \mathrm{Ca}$ ratio of 1.50 , consistent with the findings by Kaczmarek et al. ${ }^{35}$. These dolomite crystals have a rhombic shape and submicron diameter (about 0.3 to $0.8 \mu \mathrm{m}$ for reaction product of $14 \mathrm{~h}$ in the main $\mathrm{Zn}$ experiment series; Supplementary Fig. 2). This contrasts with ellipsoidal, rice-grain shaped calcite particles in the first stage of the reaction process (Supplementary Fig. 2). The 


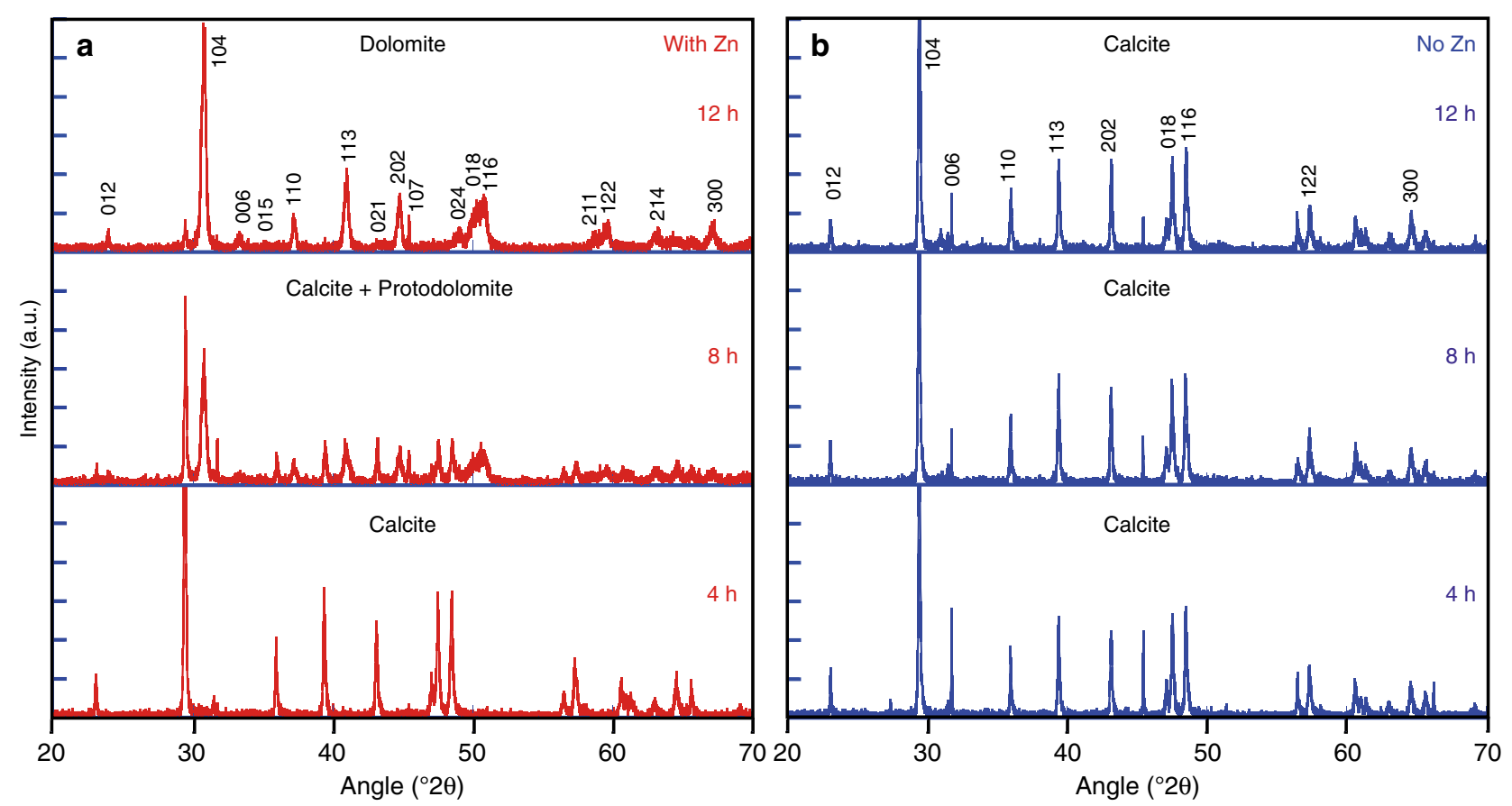

Fig. 1 Powder X-ray diffractograms (selected $20-70^{\circ} 2 \theta$ ) of reaction products in the main experiment series at selected time intervals of 4,8 , and $12 \mathrm{~h}$. The dolomite and calcite characteristic reflections are indicated in $\mathbf{a}$ and $\mathbf{b}$, respectively. The peak at $31.7^{\circ} 2 \theta$ in some diffractograms is due to minor halite that was not entirely dissolved during the rinsing process of the product or developed during drying of the samples

small size of the dolomite crystallites stems from fast nucleation and growth of the protodolomite precursor.

Effect of zinc on dolomitization rate. We found that the calciteto-dolomite replacement reaction is accelerated by the addition of dissolved $\mathrm{Zn}$ to $\mathrm{NaCl}-\mathrm{MgCl}_{2}-\mathrm{CaCl}_{2}$ aqueous solutions of constant ionic strength, with greater acceleration for higher $\mathrm{Zn}$ concentration within the range tested (Fig. 4; Supplementary Tables $1-3$ ). The main experiment series, with 0.2 weight $\% \mathrm{Zn}$, simulates natural fluids reported for the formation of carbonatehosted $\mathrm{Zn}$ sulfides ${ }^{23}$. The results reveal a significant decrease in induction time, and an increase in average reaction rate of protodolomite formation, by the addition of $\mathrm{Zn}$ in solution (Fig. 4; Supplementary Tables 2-3). The kinetics for such mineral replacement reaction can be modeled by the Avrami equation $^{5,34,36,37}$, which states that the reaction extent $y=$ $1-\exp \left[-\left(k\left(t-t_{0}\right)\right)^{n}\right]$ whereby $k$ is the rate constant, $t$ is the reaction time and $t_{0}$ the induction time, and $n$ is a time exponent that depends on the reaction mechanism ${ }^{38}$. The best fit for the Avrami model indicates an induction time of $10.5 \mathrm{~h}$, a rate constant of $3.9 \times 10^{-5} \mathrm{~s}^{-1}$, and time exponent of 2.4 for the control dolomitization reaction at $200^{\circ} \mathrm{C}$, and a lower induction time of $4.5 \mathrm{~h}$, a higher rate constant of $7.6 \times 10^{-5} \mathrm{~s}^{-1}$, and lower time exponent of 1.6 for the dolomitization experiments with $\mathrm{ZnCl}_{2}$ (Fig. 5). The geochemical and mineralogical data show that the dolomitization reaction rate in the $\mathrm{ZnO}$ experiments is very similar to that in the $\mathrm{ZnCl}_{2}$ experiments, supporting the hypothesis of the accelerating impact of $\mathrm{Zn}$ ions (Fig. 3, Supplementary Tables 3-8). The Avrami model for $\mathrm{ZnO}$ experiments indicates very similar data as for the $\mathrm{ZnCl}_{2}$ experiments, and shows an induction time of $4.5 \mathrm{~h}$, a rate constant of $7.2 \times 10^{-5} \mathrm{~s}^{-1}$ and time exponent of 1.8 (Fig. 5). In additional experiments with sulfate, we have verified that also in the presence of dissolved sulfate, which may inhibit dolomite formation under certain conditions ${ }^{14,15}$, Zn still shows a significant accelerating impact on the dolomitization rate (Supplementary Fig. 3, Supplementary Tables 9-10).

\section{Discussion}

The rate of the reaction of calcite to protodolomite is controlled by the slowest of the following three processes: transport of solutes to and from the reaction front; calcite dissolution; and protodolomite precipitation. Because of the high diffusion rate at $200^{\circ} \mathrm{C}$ and fast calcite dissolution ${ }^{39,40}$, protodolomite formation is the rate-limiting factor. Addition of $\mathrm{ZnCl}_{2}$ in the fluids decreases the $\mathrm{pH}$ from 8.6 to 6.7 (measured at $25^{\circ} \mathrm{C}$ ), caused by the formation of $\mathrm{Zn}(\mathrm{II})$ aquo complexes ${ }^{41}$. A lower $\mathrm{pH}$ is not likely to accelerate protodolomite precipitation, however, the formation of the complexes is. Among the divalent ions, $\mathrm{Mg}$ forms one of the strongest bonds with water molecules resulting in the $\left[\mathrm{Mg}\left(\mathrm{H}_{2} \mathrm{O}\right)_{6}\right]^{2+}$ complex, and this strong hydration status of $\mathrm{Mg}$ ions is accepted as a main inhibitor in rapid dolomite formation from aqueous fluids ${ }^{13}$. Molecular dynamic simulations have shown that once $\mathrm{Mg}$ ions are adsorbed onto the mineral surface, they are inhibited from diffusing into the bulk lattice by water molecules ${ }^{42}$. The addition of $\mathrm{NaCl}$ in the fluids increases the dolomite formation rate (similar to addition of $\mathrm{LiCl}$ in the study by Gaines ${ }^{43}$ ), because $\mathrm{Mg}$-water complexes are less stable in fluids of higher ionic strength, following the Debye-Hückel theory and extensions. This facilitates $\mathrm{Mg}$ dehydration for dolomite crystal formation and growth, because many water molecules form hydration shells around the $\mathrm{Na}$ and other ions in solution. For the solutions in our experiments, we calculate that there are only about 10 molecules of water per ion. Given that $\mathrm{Mg}$ can form complexes with 6 water molecules in the first hydration shell and 12 in the second hydration shell, there may be a competitive effect in ion-water complexation. Our findings demonstrate that the presence of $\mathrm{Zn}$ ions, which have a stronger hydration enthalpy than $\mathrm{Mg}$ ions, appear to promote $\mathrm{Mg}$ dehydration in aqueous solutions, whilst favouring incorporation of $\mathrm{Mg}$ into the protodolomite structure. Zinc forms strong complexes with water and several anions, and has a flexible coordination between 4, 5 and 6, which makes it an efficient catalyst in biological context ${ }^{41}$. We propose that the competitive binding affinity of $\mathrm{Zn}$ (in comparison with other metals) with water, carbonate, and chloride ${ }^{44}$ (all 


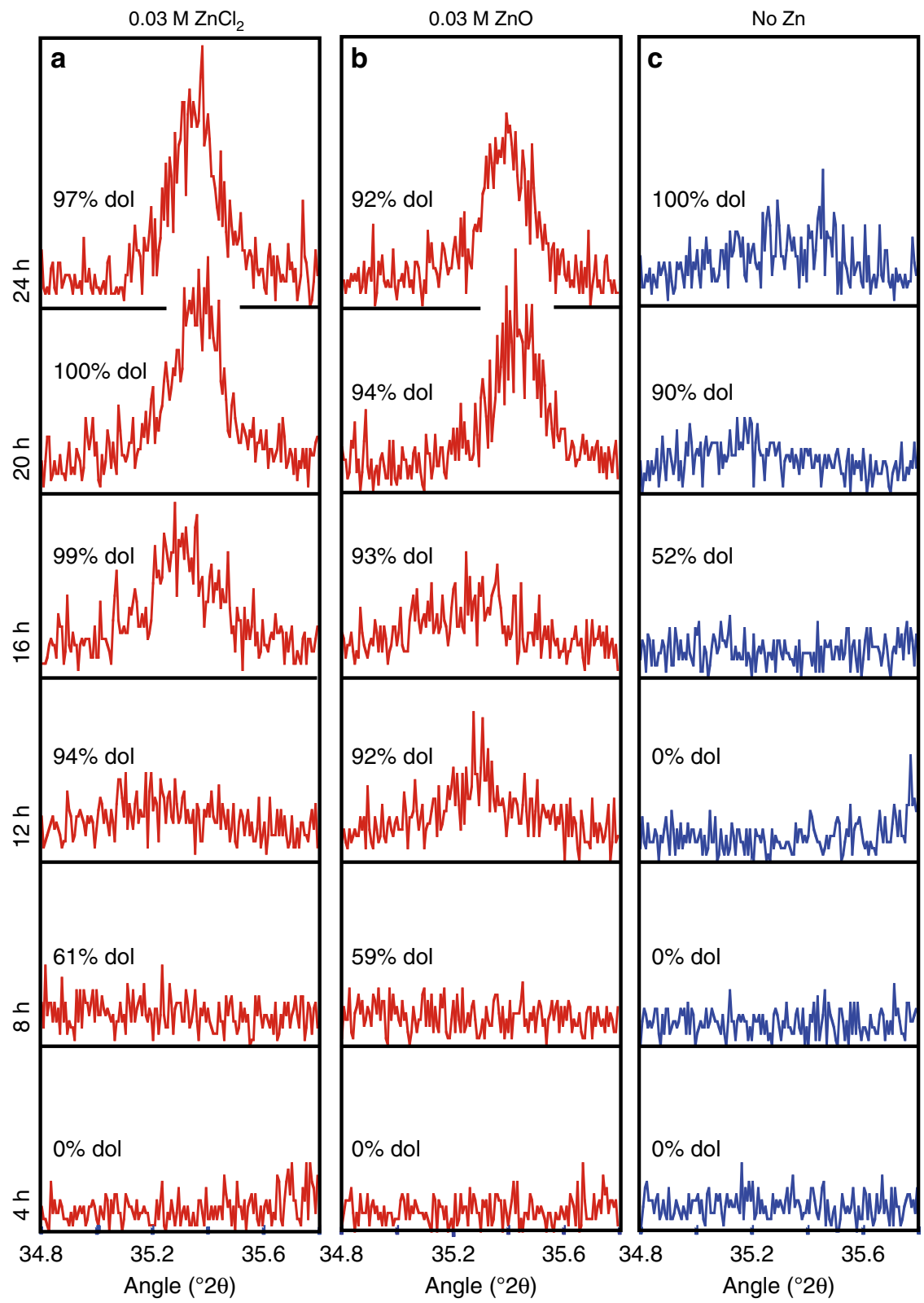

Fig. 2 Powder X-ray diffractogram selected area (34.8-35.8 $\left.{ }^{\circ} 2 \theta\right)$ of reaction products. The crystallographic data of the reaction products in the $0.03 \mathrm{M}$ $\mathrm{ZnCl}_{2}$ experiments (a), the $0.03 \mathrm{M} \mathrm{ZnO}$ experiments (b), and the $\mathrm{Zn}$-free control series (c) show that only reaction products with more than $90 \%$ dolomite contain well-ordered dolomite, giving an indication of the protodolomite to dolomite recrystallization rate. The \% dol refers to the percentage of (proto)dolomite as calculated from the main (104) dolomite peak

present in the solutions), and its easy interconversion between coordination may facilitate removal of water molecules from $\mathrm{Mg}$ water complexes at the crystal interface.

Fluids play an essential role in the mobilization of chemical elements; and fluid-rock interaction, common in the burial environment, impacts on the cycling of elements. Many MVT ore bodies are surrounded by a halo of hydrothermal dolomite ${ }^{45}$. The mineralization event, which may comprise several stages of dolomite and sulfide ore formation, involves a hydrothermal system ${ }^{46}$ with metal-rich brines, whereby either mixing with a second, sulfide-rich fluid, or in situ sulfate reduction leads to precipitation of sulfide ores ${ }^{47}$. Hydrothermal metal-rich saline fluids may have caused also dolomitization in these environments, and may help explain why MVT deposits are more commonly associated with dolostone than limestone $\mathrm{e}^{48}$.
The importance of $\mathrm{Zn}$ in accelerating carbonate formation is also identified in marine organisms, where CA, a $\mathrm{Zn}$-containing enzyme, regulates biogenic carbonate formation, as documented in corals ${ }^{49}$, sponges ${ }^{28}$, and other metazoans ${ }^{50}$. The catalytic mechanism of $\mathrm{CA}$ involves the attack of $\mathrm{Zn}$-bound $\mathrm{OH}^{-}$on a $\mathrm{CO}_{2}$ molecule loosely bound in the active center of the enzyme, and the resulting $\mathrm{Zn}$-coordinated $\mathrm{HCO}_{3}{ }^{-}$ion is then displaced from the metal ion by $\mathrm{H}_{2} \mathrm{O}$. Zinc also stimulates the production of extracellular polymeric substances ${ }^{51}$, which have been shown to catalyse dolomitization ${ }^{20}$. Zinc is an essential trace nutrient for marine microorganisms, as demonstrated by the typical nutrient cycling profile of $\mathrm{Zn}$ concentrations in the ocean, with surface depletion due to phytoplankton uptake and regeneration at depth by remineralization of sinking organic matter. Uptake of $\mathrm{HCO}_{3}{ }^{-}$ by marine diatoms is controlled by the concentrations of $\mathrm{CO}_{2}$ and of inorganic $\mathrm{Zn}$, suggesting that the availability of $\mathrm{Zn}$ may limit 

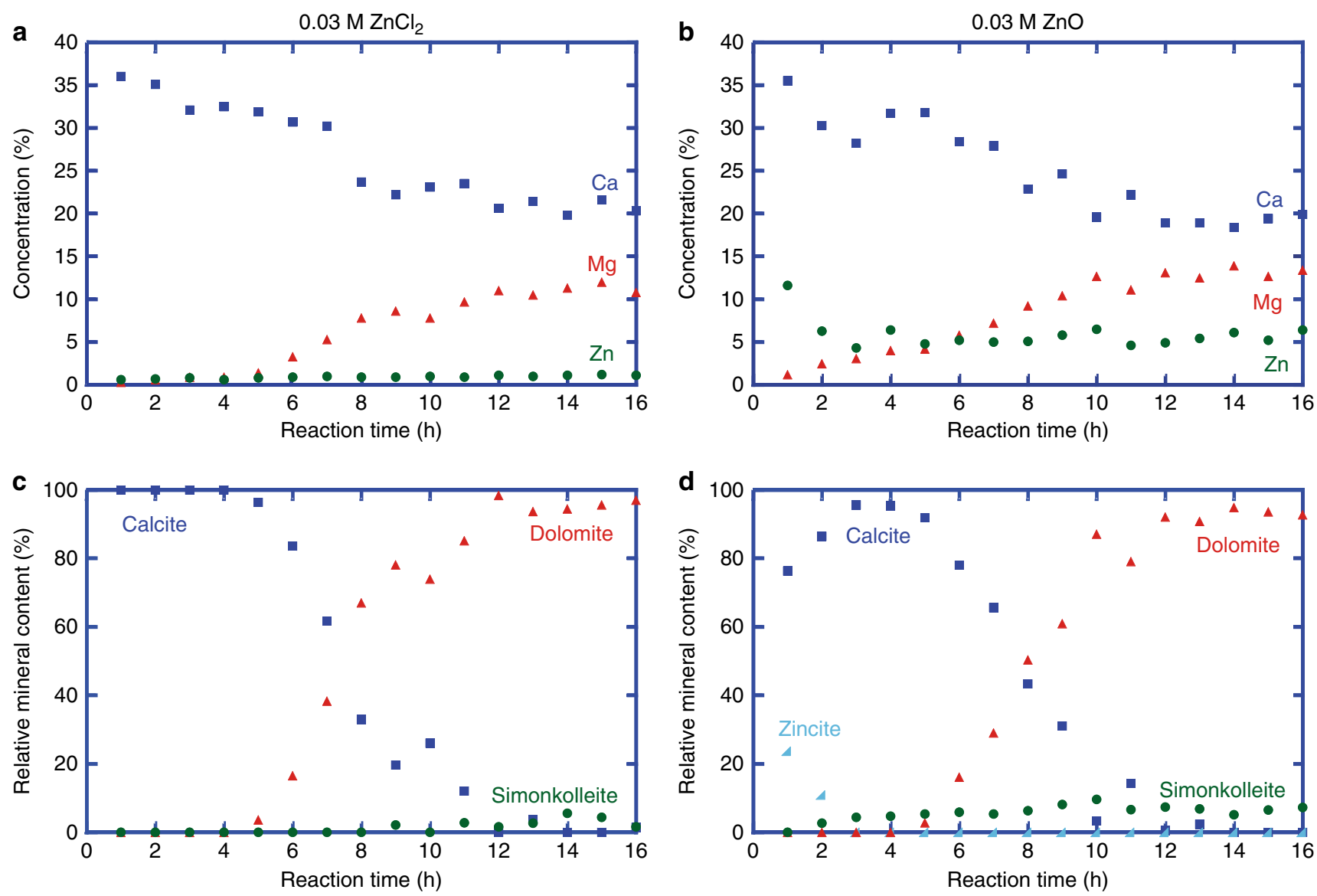

Fig. 3 Plots of geochemical and mineralogical data of reaction products against reaction time. The geochemical major element concentrations for the reaction products in the $0.03 \mathrm{M} \mathrm{ZnCl}_{2}$ experiments (a) and in the $0.03 \mathrm{M} \mathrm{ZnO}$ experiments $(\mathbf{b})$, as well as the relative mineral abundance for the reaction products in the $0.03 \mathrm{M} \mathrm{ZnCl}_{2}$ experiments (c) and in the $0.03 \mathrm{M} \mathrm{ZnO}$ experiments (d) demonstrate very similar dolomitization reaction rates which are both accelerated compared to $\mathrm{Zn}$-free solutions. The $\mathrm{ZnO}$ (zincite) experiments show dissolution of zincite within the first three hours of the experiment and significantly larger amount of simonkolleite formed in the reaction (d) compared to the $\mathrm{ZnCl}_{2}$ experiments (c)
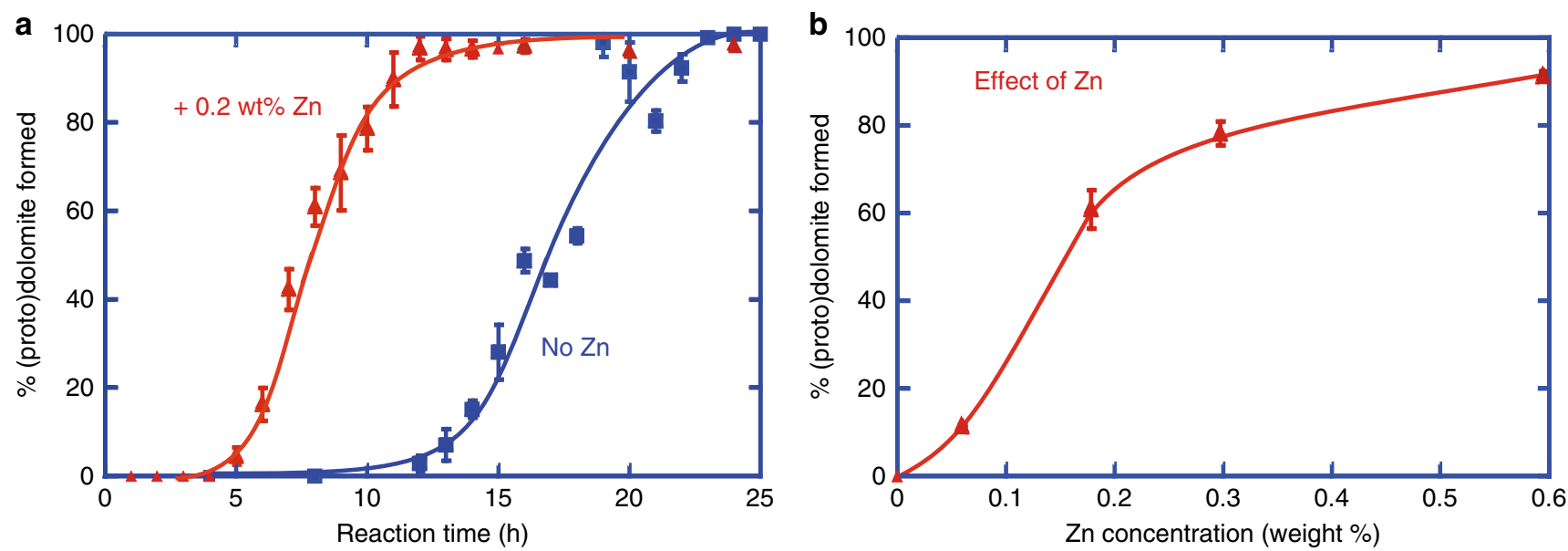

Fig. 4 Calcite-to-dolomite replacement reaction curves. a Reaction curve showing that the addition of 0.2 weight\% zinc in the fluids (red curve in comparison with blue curve) halves the time required for dolomitization of calcite at $200^{\circ} \mathrm{C}$. $\mathbf{b}$ Small amounts of zinc ions added to solutions of the same ionic strength increase significantly the amount of (proto)dolomite formed within $8 \mathrm{~h}$ reaction time. Error bars represent standard deviation of replicate samples 


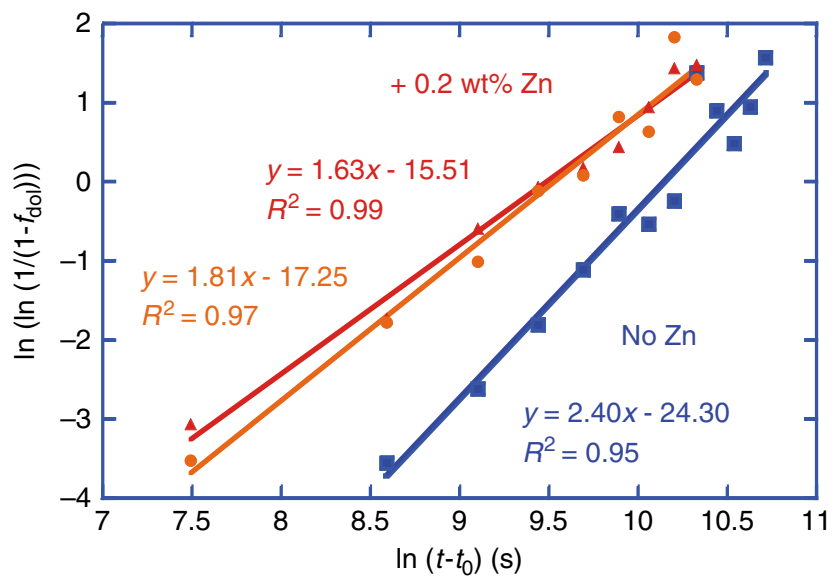

Fig. 5 Avrami plot for dolomitization of calcite at $200^{\circ} \mathrm{C}$. The linear best fit trend lines enable derivation of time exponent and rate constant for the control dolomitization experiments (blue), $\mathrm{ZnCl}_{2}$ dolomitization experiments (red), and $\mathrm{ZnO}$ dolomitization experiments (orange)

oceanic phytoplankton production and influence the global carbon cycle ${ }^{52}$. Moreover, the recently identified strong Zn-silicate linear relationship in ocean water (with vertical $\mathrm{Zn}$ and $\mathrm{Si}$ profiles showing nutrient-like distributions) demonstrates zinc's control on the efficiency of the global biological carbon pump ${ }^{53}$. This link between the geochemical $\mathrm{Zn}$ cycle and the global carbon cycle is even more important than previously thought, based on our discovery of the accelerating effect of $\mathrm{Zn}$ ions on abiotic carbonate formation in saline waters. Periods of low atmospheric oxygen and widespread marine anoxia in past climates have been favorable for the formation of abiotic authigenic carbonates in marine sediment pore fluids, representing a significant carbon $\operatorname{sink}^{54}$. Moreover, the contribution of oceanic carbonate production by marine fish ${ }^{55}$ is linked to the biological evolution through geologic time. The variation in atmospheric, biological, and geochemical conditions implies that also the type of authigenic carbonate (calcite, aragonite, dolomite) formed may have been strongly controlled, and their formation rate significantly catalyzed, by $\mathrm{Zn}$ concentrations in seawater derived fluids. An example of such climatic effect has been demonstrated in the accumulation of dolomite in coralline algae on tropical reefs ${ }^{56}$.

In conclusion, we have documented the reaction pathways and rates of calcite-to-dolomite replacement in a series of saline solutions. Our results show that the reaction rate is significantly higher in the presence of $\mathrm{Zn}$ ions. The experiments also demonstrate that $\mathrm{Zn}$ ions counteract the inhibiting effect of sulfate ions on dolomite formation (under the temperature conditions of the experiments). These observations suggest that the presence of dissolved $\mathrm{Zn}$ in saline fluids favors the dehydration of $\mathrm{Mg}$, thus enhancing its availability for incorporation in the dolomite structure. Our findings establish a previously unrecognized link between geochemical cycling (of $\mathrm{Zn}, \mathrm{Mg}, \mathrm{Ca}$, and $\mathrm{C}$ ) as part of mass transfer (geochemical element exchanges) between fluids and rocks in the Earth's crust. The dolomitization experiments in this study were conducted with fluid compositions and temperature conditions that may help explain the common association of dolomitization with MVT $\mathrm{Zn}$ ore formation. Whether these findings can be extrapolated to low temperature conditions is still a question. Future research will involve testing the effect of dissolved $\mathrm{Zn}$ on the rate of dolomitization at low temperature. Those results will then allow extending our findings across temperature scale and spatial regions. Moreover, these would enable drawing more inferences on geochemical cycling in surface sedimentary environments. This new understanding may also help explain the intriguing changes in dolomite abundance through geological time.

\section{Methods}

Batch reactor experiments. $\mathrm{CaCO}_{3}(200 \mathrm{mg})$ was reacted with $15 \mathrm{ml}$ of saline solution, as specified below, in teflon-lined steel batch reactors at $200{ }^{\circ} \mathrm{C}$. A temperature of $200^{\circ} \mathrm{C}$ was selected for the experiments based on the dual reasoning of both having relatively short reaction times, enabled by high temperature, to generate dolomite at favorable time scales for lab experimental work to test the catalytic impact of zinc, and, because this temperature falls within the temperature range at which Mississippi-Valley type zinc-lead ore deposits are formed.

Two experiment series were conducted whereby samples were taken every $4 \mathrm{~h}$ over a total time of $56 \mathrm{~h}$, with the $\mathrm{Zn}$-free control saline solution, composed of 2.00 $\mathrm{M} \mathrm{NaCl}, 0.30 \mathrm{M} \mathrm{MgCl}_{2}$ and $0.20 \mathrm{M} \mathrm{CaCl}_{2}$, and the $\mathrm{Zn}$-bearing saline solution, composed of $1.85 \mathrm{M} \mathrm{NaCl}, 0.30 \mathrm{M} \mathrm{MgCl}_{2}$ and $0.20 \mathrm{M} \mathrm{CaCl}_{2}$, and $0.05 \mathrm{M} \mathrm{ZnCl}_{2}$.

Five duplicate experiment series were conducted for a total reaction time of $8 \mathrm{~h}$ with solutions with varying dissolved zinc content, but all the same ionic strength of 3.5: $1.97 \mathrm{M} \mathrm{NaCl}, 0.30 \mathrm{M} \mathrm{MgCl}_{2}$ and $0.20 \mathrm{M} \mathrm{CaCl}_{2}$, and $0.01 \mathrm{M} \mathrm{ZnCl}_{2} ; 1.91 \mathrm{M}$ $\mathrm{NaCl}, 0.30 \mathrm{M} \mathrm{MgCl}_{2}$ and $0.20 \mathrm{M} \mathrm{CaCl}_{2}$, and $0.03 \mathrm{M} \mathrm{ZnCl}_{2} ; 1.85 \mathrm{M} \mathrm{NaCl}, 0.30 \mathrm{M}$ $\mathrm{MgCl}_{2}$ and $0.20 \mathrm{M} \mathrm{CaCl}_{2}$, and $0.05 \mathrm{M} \mathrm{ZnCl}_{2} ; 1.70 \mathrm{M} \mathrm{NaCl}, 0.30 \mathrm{M} \mathrm{MgCl}_{2}$ and 0.20 $\mathrm{M} \mathrm{CaCl}_{2}$, and $0.10 \mathrm{M} \mathrm{ZnCl}_{2} ; 1.40 \mathrm{M} \mathrm{NaCl}, 0.30 \mathrm{M} \mathrm{MgCl}_{2}$ and $0.20 \mathrm{M} \mathrm{CaCl}_{2}$, and $0.20 \mathrm{M} \mathrm{ZnCl}_{2}$.

Two triplicate experiment series were run with sampling at $1 \mathrm{~h}$ time steps and with the following solutions: $\mathrm{Zn}$-free saline (control) solution (with starting $\mathrm{pH}$ of 8.6), composed of $2.00 \mathrm{M} \mathrm{NaCl}, 0.30 \mathrm{M} \mathrm{MgCl}_{2}$ and $0.20 \mathrm{M} \mathrm{CaCl}_{2}$, in the first main series, and $\mathrm{Zn}$-bearing saline solution (with starting $\mathrm{pH}$ of 6.7), composed of 1.91 $\mathrm{M} \mathrm{NaCl}, 0.30 \mathrm{M} \mathrm{MgCl}_{2}$ and $0.20 \mathrm{M} \mathrm{CaCl}_{2}$, and $0.03 \mathrm{M} \mathrm{ZnCl}_{2}$, in the second main series. The $\mathrm{Zn}$ concentration in the latter fluid is 0.2 weight $\%$, similar to that reported in Irish-type $\mathrm{Zn}$ sulfides $^{16}$. The fluids were all set to have the same ionic strength of 3.50 .

The presence of traces of $\mathrm{ZnO}$ in the reaction products of the $\mathrm{ZnCl}_{2}$ experiments triggered the set-up of an additional experiment series (with $1 \mathrm{~h}$ time step sampling) whereby $200 \mathrm{mg}$ of calcite and $36.6 \mathrm{mg}$ of $\mathrm{ZnO}$ was reacted with 15 $\mathrm{ml}$ of a saline solution composed of $2.00 \mathrm{M} \mathrm{NaCl}, 0.30 \mathrm{M} \mathrm{MgCl}_{2}$, and $0.20 \mathrm{M} \mathrm{CaCl}_{2}$. The amount of zinc in those experiments is equivalent to the amount used in the $\mathrm{ZnCl}_{2}$ experiments. Furthermore, we tested the impact of $\mathrm{Zn}$ in the presence of sulfate, given the known inhibiting effect of sulfate on dolomite formation. Two experiments series were set up whereby $200 \mathrm{mg}$ of calcite was reacted with $15 \mathrm{ml}$ of solution: $\mathrm{Zn}$-free saline (control) solution with sulfate, composed of $2.00 \mathrm{M} \mathrm{NaCl}$ $0.27 \mathrm{M} \mathrm{MgCl}_{2}, 0.03 \mathrm{M} \mathrm{MgSO}_{4}$, and $0.20 \mathrm{M} \mathrm{CaCl}_{2}$, in the first main series, and $\mathrm{Zn}$ bearing saline solution with sulfate, composed of $2.00 \mathrm{M} \mathrm{NaCl}, 0.30 \mathrm{M} \mathrm{MgCl}_{2}$ and $0.20 \mathrm{M} \mathrm{CaCl}_{2}$, and $0.03 \mathrm{M} \mathrm{ZnSO}_{4}$, in the second main series. These reactions were conducted at $200^{\circ} \mathrm{C}$ for a series of reaction times (12, 24, 30, 36, 48, 60, and $72 \mathrm{~h}$ ). Calcite powder was purchased from Acros Organics, $\mathrm{NaCl}$ from $\mathrm{VWR}, \mathrm{CaCl}_{2}$ from Merck, $\mathrm{MgCl}_{2}, \mathrm{MgSO}_{4}$ and $\mathrm{ZnSO}_{4} .7 \mathrm{H}_{2} \mathrm{O}$ from Alfa Aesar, $\mathrm{ZnCl}_{2}$ from Sigma Aldrich and $\mathrm{ZnO}$ from Honeywell.

Calcite reactant morphology and surface area analysis. Individual calcite grains were determined to be submicrometer size based on scanning electron microscopy (SEM) and energy dispersive spectrometry (EDS) analysis. The SEM and EDS analyses were performed on a Quanta 650 with an $150 \mathrm{~mm}$ Oxford Instruments $\mathrm{X}-\mathrm{Max}$ detector at $10-15 \mathrm{kV}$, spot 2.5-4. Triplicate BET analyses were performed on the calcite powders using Micromeritics 3Flex surface characterization and nitrogen gas. The calcite powder has a $\mathrm{N}_{2}$ Brunauer-Emmett-Teller (BET) surface area of $8.72 \pm 0.04 \mathrm{~m}^{2} \mathrm{~g}^{-1}$.

Mineralogy and geochemistry of reaction products. The reaction products from the batch reactor experiments were collected by transfer to centrifuge tubes and cleaned three times with milliQ water, decanting the liquid after centrifugation at $4500 \mathrm{rpm}$ for $5 \mathrm{~min}$. This cleaning procedure should dissolve and remove most of the $\mathrm{NaCl}$ salt from the products. The residue was subsequently dried in an oven at $60{ }^{\circ} \mathrm{C}$. The weight of the reaction product was then recorded. Complete replacement of $200 \mathrm{mg}$ calcite is expected to result in $184 \mathrm{mg}$ dolomite. Identification of the reaction product, dolomite, was conducted by PXRD, EDS-SEM analysis and ICP-OES analysis. The reaction extent was derived from the calcite and dolomite abundance in the reaction products, and verified by the expected weight of the reaction products (based on mole-per-mole replacement reaction), which was consistent in all cases (with up to $5 \%$ error as derived from triplicate experiments).

For PXRD analysis, the samples were scanned over a sampling range of 5 to $70{ }^{\circ} 2 \theta$, with a step size of 0.0066 and a scan speed of $0.023^{\circ} 2 \theta$ per second. A PANalytical X'Pert Pro was used for these analyses with CuKa radiation at $40 \mathrm{kV}$ and $40 \mathrm{~mA}$. A $5 \mathrm{~mm}$ mask was used because of the relatively small size of the samples contained in custom-built holders. Calcite and minor halite peaks in the samples were used as internal reference to assess machine drift. The relative ratios of dolomite and calcite in the samples were calculated based on the ratio of respective main peak areas. The background noise was removed before calculating integrated peak areas for the minerals detected to determine relative ratios of mineral abundance. 
For geochemical analysis of the reaction products, $10 \mathrm{mg}$ of the precipitate was dissolved in $10 \mathrm{ml} 5 \% \mathrm{HNO}_{3}$ in small closed teflon reactors at $80^{\circ} \mathrm{C}$ for one hour. Upon cooling, the solutions were transferred to centrifuge tubes, and centrifuged at $4500 \mathrm{rpm}$ for $5 \mathrm{~min}$. The fluid samples were then measured using a Perkin Elmer spectrometer Optima 2000 DV. A standard solution containing 28 elements at 100 ppm (Fisher Chemicals) was used to make a calibration series of $0.1,1,3,5,7$, and $10 \mathrm{ppm}$ solutions, made with $2 \% \mathrm{HNO}_{3}$. Sample fluids were diluted as necessary to obtain concentrations falling well within the calibration range.

\section{Data availability}

The quantitative data for each of the samples from this study as well as the Tables and Figures in the Supplementary Files are available in the EarthChem Library (https://doi. org/10.1594/IEDA/111274). Additional information related to this paper can be obtained from the corresponding author upon request.

Received: 7 August 2018 Accepted: 2 April 2019

Published online: 23 April 2019

\section{References}

1. Falkowski, P. et al. The global carbon cycle: a test of our knowledge of earth as a system. Science 290, 291-296 (2000).

2. Frank, D. C. et al. Ensemble reconstruction constraints on the global carbon cycle sensitivity to climate. Nature 463, 527-U143 (2010).

3. McKenzie, J. A. In Controversies in Modern Geology: Evolution of Geochemical Theories in Sedimentology, Earth History and Tectonics (eds Müller, D. W., McKenzie, J. A. \& Weissert, H.) 37-54 (Academic Press, Cambridge, MA, 1991).

4. Warren, J. Dolomite: occurrence, evolution and economically important associations. Earth-Sci. Rev. 52, 1-81 (2000).

5. Sibley, D. F., Dedoes, R. E. \& Bartlett, T. R. Kinetics of dolomitization. Geology 15, 1112-1114 (1987).

6. Brady, P. V., Krumhansl, J. L. \& Papenguth, H. W. Surface complexation clues to dolomite growth. Geochim. Et. Cosmochim. Acta 60, 727-731 (1996).

7. $\mathrm{Xu}$, J. et al. Testing the cation-hydration effect on the crystallization of Ca-Mg$\mathrm{CO}_{3}$ systems. Proc. Natl Acad. Sci. USA 110, 17750-17755 (2013).

8. Hong, M., Xu, J. \& Teng, H. H. Evolution of calcite growth morphology in the presence of magnesium: implications for the dolomite problem. Geochim. Et. Cosmochim. Acta 172, 55-64 (2016).

9. Davis, K. J., Dove, P. M. \& De Yoreo, J. J. The role of $\mathrm{Mg} 2+$ as an impurity in calcite growth. Science 290, 1134-1137 (2000).

10. Fenter, P. et al. Structure and reactivity of the dolomite (104)-water interface: new insights into the dolomite problem. Geochim. Et. Cosmochim. Acta 71, 566-579 (2007).

11. Astilleros, J. M., Fernandez-Diaz, L. \& Putnis, A. The role of magnesium in the growth of calcite: an AFM study. Chem. Geol. 271, 52-58 (2010).

12. Gregg, J. M., Bish, D. L., Kaczmarek, S. E. \& Machel, H. G. Mineralogy, nucleation and growth of dolomite in the laboratory and sedimentary environment: a review. Sedimentology 62, 1749-1769 (2015).

13. Zhang, F. et al. Dissolved sulfide-catalyzed precipitation of disordered dolomite: Implications for the formation mechanism of sedimentary dolomite. Geochim. Et. Cosmochim. Acta 97, 148-165 (2012).

14. Baker, P. A. \& Kastner, M. Constraints on the formation of sedimentary dolomite. Science 213, 214-216 (1981).

15. Petrash, D. A. et al. Microbially catalyzed dolomite formation: From nearsurface to burial. Earth-Sci. Rev. 171, 558-582 (2017).

16. Sánchez-Román, M., McKenzie, J. A., Wagener, A., Rivadeneyra, M. A. \& Vasconcelos, C. Presence of sulfate does not inhibit low-temperature dolomite precipitation. Earth Planet. Sci. Lett. 285, 131-139 (2009).

17. Brady, P. V., Papenguth, H. W. \& Kelly, J. W. Metal sorption to dolomite surfaces. Appl. Geochem. 14, 569-579 (1999).

18. Vasconcelos, C., McKenzie, J. A., Bernasconi, S., Grujic, D. \& Tien, A. J. Microbial mediation as a possible mechanism for natural dolomite formation at low temperatures. Nature 377, 220-222 (1995).

19. Krause, S. et al. Microbial nucleation of Mg-rich dolomite in exopolymeric substances under anoxic modern seawater salinity: New insight into an old enigma. Geology 40, 587-590 (2012)

20. Zhang, F. et al. The catalytic effect of bound extracellular polymeric substances excreted by anaerobic microorganisms on $\mathrm{Ca}-\mathrm{Mg}$ carbonate precipitation: implications for the "dolomite problem". Am. Mineral. 100, 483-494 (2015).

21. Roberts, J. A. et al. Surface chemistry allows for abiotic precipitation of dolomite at low temperature. Proc. Natl Acad. Sci. USA 110, 14540-14545 (2013).

22. Shelton, K. L., Gregg, J. M. \& Johnson, A. W. Replacement dolomites and ore sulfides as recorders of multiple fluids and fluid sources in the Southeast
Missouri Mississippi Valley-Type District: halogen-Sr-87/Sr-86-delta O-18delta S-34 systematics in the Bonneterre Dolomite. Econ. Geol. 104, 733-748 (2009).

23. Wilkinson, J. J., Stoffell, B., Wilkinson, C. C., Jeffries, T. E. \& Appold, M. S. Anomalously metal-rich fluids form hydrothermal ore deposits. Science 323, 764-767 (2009).

24. Vandeginste, V. et al. Geochemical constraints on the origin of the Kicking Horse and Monarch Mississippi Valley-type lead-zinc ore deposits, southeast British Columbia, Canada. Miner. Depos. 42, 913-935 (2007).

25. Smith, D. W. Ionic hydration enthalpies. J. Chem. Educ. 54, 540-542 (1977).

26. Chi, T. et al. A Drosophila model identifies a critical role for zinc in mineralization for kidney stone disease. Plos One 10, e0124150 (2015).

27. Mansfield, C. F. A urolith of biogenic dolomite - another clue in the dolomite mystery. Geochim. Et. Cosmochim. Acta 44, 829-839 (1980).

28. Mueller, W. E. G. et al. Enzyme-accelerated and structure-guided crystallization of calcium carbonate: role of the carbonic anhydrase in the homologous system. Acta Biomater. 10, 450-462 (2014).

29. Molva, M., Kilic, S. \& Ozdemir, E. Effect of carbonic anhydrase on $\mathrm{CaCO}_{3}$ crystallization in alkaline solution. Energy Fuels 30, 10686-10695 (2016).

30. Boni, M. \& Mondillo, N. The "Calamines" and the "Others": The great family of supergene nonsulfide zinc ores. Ore Geol. Rev. 67, 208-233 (2015).

31. Boni, M., Mondillo, N. \& Balassone, G. Zincian dolomite: a peculiar dedolomitization case? Geology 39, 183-186 (2011).

32. Putnis, A. Why mineral interfaces matter. Science 343, 1441-1442 (2014).

33. Etschmann, B. et al. Grain boundaries as microreactors during reactive fluid flow: experimental dolomitization of a calcite marble. Contributions Mineral. Petrol. 168, https://doi.org/10.1007/s00410-014-1045-z (2014).

34. Rodriguez-Blanco, J. D., Shaw, S. \& Benning, L. G. A route for the direct crystallization of dolomite. Am. Mineral. 100, 1172-1181 (2015).

35. Kaczmarek, S. E. \& Sibley, D. F. On the evolution of dolomite stoichiometry and cation order during high-temperature synthesis experiments: an alternative model for the geochemical evolution of natural dolomites. Sediment. Geol. 240, 30-40 (2011).

36. Xia, F. et al. Mechanism and kinetics of pseudomorphic mineral replacement reactions: a case study of the replacement of pentlandite by violarite. Geochim. Et. Cosmochim. Acta 73, 1945-1969 (2009).

37. Sibley, D. F. Unstable to stable transformations during dolomitization. J. Geol. 98, 739-748 (1990)

38. Avrami, M. Kinetics of phase change. I General theory. J. Chem. Phys. 7, 1103-1112 (1939).

39. Sjoberg, E. L. \& Rickard, D. T. Temperature dependance of calcite dissolution kinetics between 1 degree $\mathrm{C}$ and 62 degrees $\mathrm{C}$ at $\mathrm{pH}$ of 2.7 to 8.4 in aqueous solutions. Geochim. Et. Cosmochim. Acta 48, 485-493 (1984).

40. Colombani, J. The alkaline dissolution rate of calcite. J. Phys. Chem. Lett. 7 , 2376-2380 (2016).

41. Krezel, A. \& Maret, W. The biological inorganic chemistry of zinc ions. Arch Biochem. Biophys. 611, 3-19 (2016).

42. de Leeuw, N. H. \& Parker, S. C. Surface-water interactions in the dolomite problem. Phys. Chem. Chem. Phys. 3, 3217-3221 (2001).

43. Gaines, A. M. Protodolomite synthesis at $100^{\circ} \mathrm{C}$ and atmospheric pressure. Science 183, 518-520 (1974).

44. Mei, Y. et al. Zinc complexation in chloride-rich hydrothermal fluids (25-600 ${ }^{\circ} \mathrm{C}$ ): A thermodynamic model derived from ab initio molecular dynamics. Geochim. Et. Cosmochim. Acta 150, 265-284 (2015).

45. Reid, S., Dewing, K. \& Sharp, R. Polaris as a guide to northern exploration: ore textures, paragenesis and the origin of the carbonate-hosted Polaris $\mathrm{Zn}-\mathrm{Pb}$ Mine, Nunavut, Canada. Ore Geol. Rev. 51, 27-42 (2013).

46. Symons, D. T. A., Tornos, F., Kawasaki, K., Velasco, F. \& Rosales, I. Genetic constraints from paleomagnetic dating for the Aliva zinc-lead deposit, Picos de Europa Unit, northern Spain. Miner. Depos. 50, 953-966 (2015).

47. Leach, D. L. et al. Sediment-hosted lead-zinc deposits: a global perspective. Econ. Geol. 100, 561-607 (2005).

48. Paradis, S., Hannigan, P. \& Dewing, K. In Mineral Deposits of Canada: A Synthesis of Major Deposit-types, Sitrict Metallogeny, The Evolution of Geological Provinces, and Exploration Methods Vol. 5 (ed Goodfellow, W. D.) 185-203 (Geological Association of Canada, Mineral Deposits Division, Special Publication, 2007).

49. Bertucci, A. et al. Carbonic anhydrases in anthozoan corals-A review. Bioorg. Med. Chem. 21, 1437-1450 (2013).

50. Le Roy, N., Jackson, D. J., Marie, B., Ramos-Silva, P. \& Marin, F. The evolution of metazoan alpha-carbonic anhydrases and their roles in calcium carbonate biomineralization. Front. Zool. 11, https://doi.org/10.1186/s12983014-0075-8 (2014).

51. Redmile-Gordon, M. \& Chen, L. Zinc toxicity stimulates microbial production of extracellular polymers in a copiotrophic acid soil. Int. Biodeter. Biodegr. 119, 413-418 (2017).

52. Morel, F. M. M. et al. Zinc and carbon co-limitation of marine-phytoplankton. Nature 369, 740-742 (1994). 
53. Wyatt, N. J. et al. Biogeochemical cycling of dissolved zinc along the GEOTRACES South Atlantic transect GA10 at 40 S. Glob. Biogeochem. Cycles 28, 44-56 (2014).

54. Schrag, D. P., Higgins, J. A., Macdonald, F. A. \& Johnston, D. T. Authigenic carbonate and the history of the global carbon cycle. Science 339, 540-543 (2013).

55. Wilson, R. W. et al. Contribution of fish to the marine inorganic carbon cycle. Science 323, 359-362 (2009).

56. Diaz-Pulido, G. et al. Greenhouse conditions induce mineralogical changes and dolomite accumulation in coralline algae on tropical reefs. Nat. Commun. 5, https://doi.org/10.1038/ncomms4310 (2014).

\section{Acknowledgements}

We thank William Lewis for maintenance of the powder X-ray diffractometer, Mark Guyler and Ben Pointer-Gleadhill for the ICP-OES in the School of Chemistry, and Aleksandra Gonciaruk for help with the BET analyses in the Gas Adsorption Analysis Suite lab in Engineering. The manuscript has significantly improved by discussions and review of drafts by Neil Champness, Martyn Poliakoff, Liam Ball, Hon Lam, Matthew Jones, Paul Nathaniel, David Large, Deborah Kays, and Jonathan McMaster. Funding: We acknowledge support by the Engineering and Physical Sciences Research Council (EPSRC) under grant no. EP/K005138/1 and grant no. EP/M000567/1, and the British Geological Survey and Strategic Development Fund for the GeoEnergy Research Centre.

\section{Author contributions}

V.V. designed the research and carried out the experiments and analyses unless otherwise stated. O.S. carried out preliminary experimental tests. E.S. performed the SEM-EDS analyses. A.V. developed software for data analysis. V.V., O.S., M.R.H., E.S., A.V, contributed to interpretation of the results.

\section{Additional information}

Supplementary Information accompanies this paper at https://doi.org/10.1038/s41467 019-09870-y.

Competing interests: The authors declare no competing interests.

Reprints and permission information is available online at http://npg.nature.com/ reprintsandpermissions/

Journal peer review information: Nature Communications thanks Rolf Arvidson and other anonymous reviewer(s) for their contribution to the peer review of this work. Peer reviewer reports are available.

Publisher's note: Springer Nature remains neutral with regard to jurisdictional claims in published maps and institutional affiliations.

(c) Open Access This article is licensed under a Creative Commons Attribution 4.0 International License, which permits use, sharing, adaptation, distribution and reproduction in any medium or format, as long as you give appropriate credit to the original author(s) and the source, provide a link to the Creative Commons license, and indicate if changes were made. The images or other third party material in this article are included in the article's Creative Commons license, unless indicated otherwise in a credit line to the material. If material is not included in the article's Creative Commons license and your intended use is not permitted by statutory regulation or exceeds the permitted use, you will need to obtain permission directly from the copyright holder. To view a copy of this license, visit http://creativecommons.org/ licenses/by/4.0/.

(C) The Author(s) 2019 